\title{
Distribution and structure of lotic macroinvertebrate communities and the influence of environmental factors in a tropical cloud forest, Cusuco National Park, Honduras
}

\author{
Paul O’CALLAGHAN,,$^{1,2^{*}}$ Mary KELLY-QUINN ${ }^{1}$
}

${ }^{1}$ School of Biology and Environmental Science, Science Centre West, University College Dublin, Belfield, Dublin 4, Ireland; ${ }^{2}$ Operation Wallacea, Wallace House, Old Bolingbroke, Spilsby, Lincolnshire, PE23 4EX, UK

*Corresponding author: paul.ocallaghan@ucd.ie

\begin{abstract}
Neotropical cloud forests are a critically endangered ecosystem characterised by their unusual hydrological conditions which frequently make them important sources of clean potable water. To facilitate any meaningful research on cloud forest streams it is necessary to first describe the structure and composition of the local lotic aquatic communities and to establish which environmental factors structure them under natural conditions. The present study sampled the macroinvertebrate communities of rivers draining the montane cloud forests of Cucuso National Park in Honduras, where increasing anthropogenic pressures are threatening water quality. Using multivariate techniques a bottom-up approach was adopted to establish groups of similar sites and identify environmental factors driving the differences between these. Three site groupings emerged based largely on differences in taxon composition driven mainly by $\mathrm{pH}$ and altitude.
\end{abstract}

Key words: Stream macroinvertebrate composition; environmental; typology; Neotropics; Mesoamerica.

Received: June 2016. Accepted: October 2016.

\section{INTRODUCTION}

Neotropical montane cloud forests are hydrologically unique, critically endangered ecosystems and frequently major sources of potable water, which have come under increasing pressure from human activities. Making up just $2.5 \%$ of the world's tropical forest (Bubb et al., 2004) they are of disproportional conservation importance. Not only are they home to numerous endangered species but they also display an extremely high degree of endemicity (Doumenge et al., 1995; Hamilton, 1995; Hostettler, 2002; González-Espinosa et al., 2011). They are also important as genetic refugia for wild relatives of some of the world's most important commercial crop plants including coffee, strawberry, raspberry, blueberry and gooseberry (Bruijnzeel and Hamilton, 2000; Bubb et al., 2004). However, arguably the most important aspect of cloud forests is their unusual hydrological features and role in protecting water resources and quality in headwater streams. Net precipitation (rain through fall) in cloud forests is significantly subsidised by fog interception (often called occult precipitation, horizontal precipitation or fog/cloud stripping) (Hamilton, 1995; Bruijnzeel and Hamilton, 2000; Hostettler, 2002). This in combination with lower solar radiation and a generally wet canopy (both of which have a role in reducing evapotranspiration) increases the water budget of the catchment and together with the moderating effect of natural forest on wa- terways results in a remarkably reliable and clean water resource. However, cloud forests and therefore the water resources they protect have come under increasing pressure from a variety of sources including airborne contaminants, alien species, harvesting of forest products, disease and climate change. Deforestation for plantations such as coffee, bananas and illegal and legal drugs as well as pasture mostly for cattle and sheep probably poses the greatest landscape threat (Doumenge et al., 1995; Hamilton, 1995). Furthermore, due to their high biodiversity, unique gene pools, small size and slow recovery after disturbance the removal of individual cloud forests is considered irreversible (Bruijnzeel and Hamilton, 2000).

Williams (1988) stated that 'the subjects of studies have been and largely remain excessively concerned with northern temperate fresh waters and associated problems'. To what extent concepts derived in the temperate zone apply to neotropical systems remains largely unclear. Thus basing management decisions on assumptions founded in temperate freshwater research is at best tenuous (Wantzen et al., 2006; Boulton et al., 2008). While there has been growing interest in neotropical streams generally (Covich, 1988; Jackson and Sweeney, 1995a, 1995b) and particularly in the use of bioassessment tools to evaluate and protect their water quality (Fenoglio et al., 2002; Maue and Springer, 2008; Bücker et al., 2010) as well as recognition of the conservation importance of 
cloud forests and associated ecosystem services they supply, relative to other regions and systems there is a dearth of basic ecological and particularly taxonomic information available on neotropical cloud forest streams. Efforts to build on existing knowledge on neotropical streams generally have been hampered by a lack of taxonomic expertise and local reference collections in the neotropics (Springer, 1998) and with a few notable exceptions such as Edmunds et al. (1976); Förster (2001) and Springer et al. (2010) there is still a lack of basic taxonomic information and identification keys. This is particularly true of Honduras where very few studies have been conducted and taxonomic knowledge is still quite limited, a situation which may be exacerbated by data from some studies remaining unpublished (Lopez and Mora, 2014). Broadly speaking few sweeping generalisations can be made which distinguish tropical streams from those in temperate regions. However, several differences have been highlighted, namely tropical streams tend to receive more solar radiation, more intense rainfall, often have warmer water, less dissolved oxygen, more predictable floods and many taxonomic groups with high species diversity (Boultan et al., 2008). Furthermore differences in trophic guild structure exist for example it has been suggested that there is a paucity of invertebrate shredders in these systems (Dobson et al., 2002; Li and Dudgeon, 2009), that this role may be filled by crabs (Dobson et al., 2002), shrimp (Crowl et al., 2001), microbiota (Mathuriau and Chauvet, 2002; Gonçalves et al., 2006) or more recently, that the use of literature based in temperate regions to assign functional feeding groups in tropical studies has led to the underestimation of shredders (Masese et al., 2014). Much work remains to fully understand how these features of tropical streams combine to structure aquatic communities.

An obligate step towards understanding any ecosystem is the acquisition of data on and characterisation of the composition and structure of communities in unimpacted systems and the natural environmental factors structuring those communities (Johnson, 1998; Verdonschot and Nijboer, 2004; Ferréol et al., 2005; Sandin and Verdonschot, 2006; Turak and Koop, 2008; Bücker et al., 2010; Dudgeon, 2012). While several studies of this nature have been undertaken in recent years in neotropical freshwater streams, for example Bücker et al. (2010), Moya et al. (2011) and Carrie et al. (2015) descriptive studies of this nature are still relatively few in the region and much work remains to be done. Furthermore this has been identified as a research priority for freshwater ecosystems in Honduras by Lopez and Mora (2014) who go on to describe the availability of information on freshwater communities and their habitats in Honduras as practically nil and to emphasise the particular importance of research on the subject in protected areas. The objectives of this study were to describe the structure and composition of the lotic macroinvertebrate community of a tropical cloud forest, Cusuco National Park, Honduras, to assess whether sites could be grouped based on similarities in their macroinvertebrate assemblages and if so to determine which physicochemical variables were driving the differences between those groups. To the author's knowledge only one other study has examined environmental factors structuring macroinvertebrate communities in Honduras (López et al., 2010), this was an examination of the applicability of the river continuum concept to Honduran streams.

\section{METHODS}

The data were collected from El Parque Nacional Cusuco in the Merendon Mountains region of northern Honduras ( $15^{\circ} 29^{\prime} 41.028^{\prime \prime} \mathrm{N}$ and $\left.88^{\circ} 12^{\prime} 48.4554^{\prime \prime} \mathrm{W}\right)$ during the wet season from June to August 2009, 2010 and 2011. These sites had not been previously sampled or characterised and so little information was available on their physical or chemical characteristics. In total $31 \mathrm{~min}$ imally impacted sites were chosen across 7 catchments. These were chosen using a GIS model to gain the greatest spatial distribution across the national park (Fig. 1) whilst taking into account accessibility. Where possible selected catchments were sampled across an altitudinal gradient. Twenty one low order $\left(1^{\text {st }}-3^{\text {rd }}\right.$, maximum catchment 5.47 $\mathrm{km}^{2}$ ) upland sites were sampled in 2009, 27 in 2010 (16 of which were repeat samples of 2009 sites), and 5 sites in 2011, all of which had previously been sampled.

Abiotic factors recorded included substrate representation and percentage shade which were visually estimated, altitude and slope calculated from GIS maps, oxygen concentration and percentage saturation, $\mathrm{pH}$, and concentrations of phosphate, nitrate, nitrite, ammonium, total hardness, alkalinity and dissolved iron (Tabs. 1 and 2). Oxygen, $\mathrm{pH}$ and temperature were measured in situ at the time of invertebrate sampling (using a WTW oxi330 probe, and a Hanna instruments HI98129 $\mathrm{pH}$ probe respectively) while nutrient (phosphate, nitrate, nitrite, ammonium), total hardness and iron analyses were one-off measurements made in 2011 due to difficulties associated with transport of samples and access to analytical facilities associated with such a remote location. Therefore, water samples were returned to camp and analyses were undertaken using a Merck spectroquant nova 60 mobile spectrophotometer and Merck Spectroquant photometric cell test kits following the methods described for each kit (Tab. 2).

Three replicate 2-minute macroinvertebrate kick samples were taken with a standard pond net $(1000 \mu \mathrm{m}$ mesh $)$ at each site using a multi-habitat sampling procedure with time spent sampling each habitat type (with habitats based of flow type and proportioned visually i.e. riffle, run, pool), spent proportional to its occurrence (percentage cover) at the site (Wright et al., 1998). Samples were re- 
turned to the nearest camp to be live sorted and the extracted macroinvertebrates were preserved in $70 \%$ ethanol. Specimens were exported to University College Dublin for identification and enumeration to the lowest taxonomic level possible. The macroinvertebrate database was standardised and where taxa were identified to different taxonomic levels in different sites these were brought to the same level for statistical analysis.

A bottom-up methodology, grouping sites based on their macroinvertebrate assemblages, was adopted. Statistical analysis was performed on 2010 data for which water chemistry was available which included most of the 2009 and 2011 sites as well as several additional sites. Invertebrate data were standardised, rare taxa removed and log $(\mathrm{x}+1)$ transformed to reduce the influence of very abundant taxa. Groups of sites with similar macroinvertebrate communities were identified using CLUSTER analysis. This is an agglomerative hierarchical clustering technique which produces a dendrogram showing similarity groupings. The SIMilarity PROFile test (SIMPROF) was applied. This is a permutation test of the null hypothesis that a specified set of samples, which are not a priori divided into groups, do not differ from each other in multivariate structure. SIMPROF looks for genuine clusters and can display those that are statistically different on a CLUSTER dendrogram (Clarke and Gorley, 2006). The significance level for the SIMPROF test was set at $1 \%$.

A disadvantage of using hierarchical techniques is that groups formed early in the process cannot be broken and may influence groups formed later. The dendrogram therefore may not be a representation of all pairwise dissimilarities (Quinn and Keough, 2002). Another method to graphically represent the dissimilarities between the communities, verify the groups derived from the CLUSTER analysis and to ascertain which environmental variables were driving the differences between these groups, a Principal Coordinate Analysis (PCoA) was therefore performed on the biological data. This was overlaid with the groups derived from CLUSTER analysis as well as vectors representing environmental data. Environmental variables that are influenced by anthropogenic impact were excluded from the PCoA analyses, those included

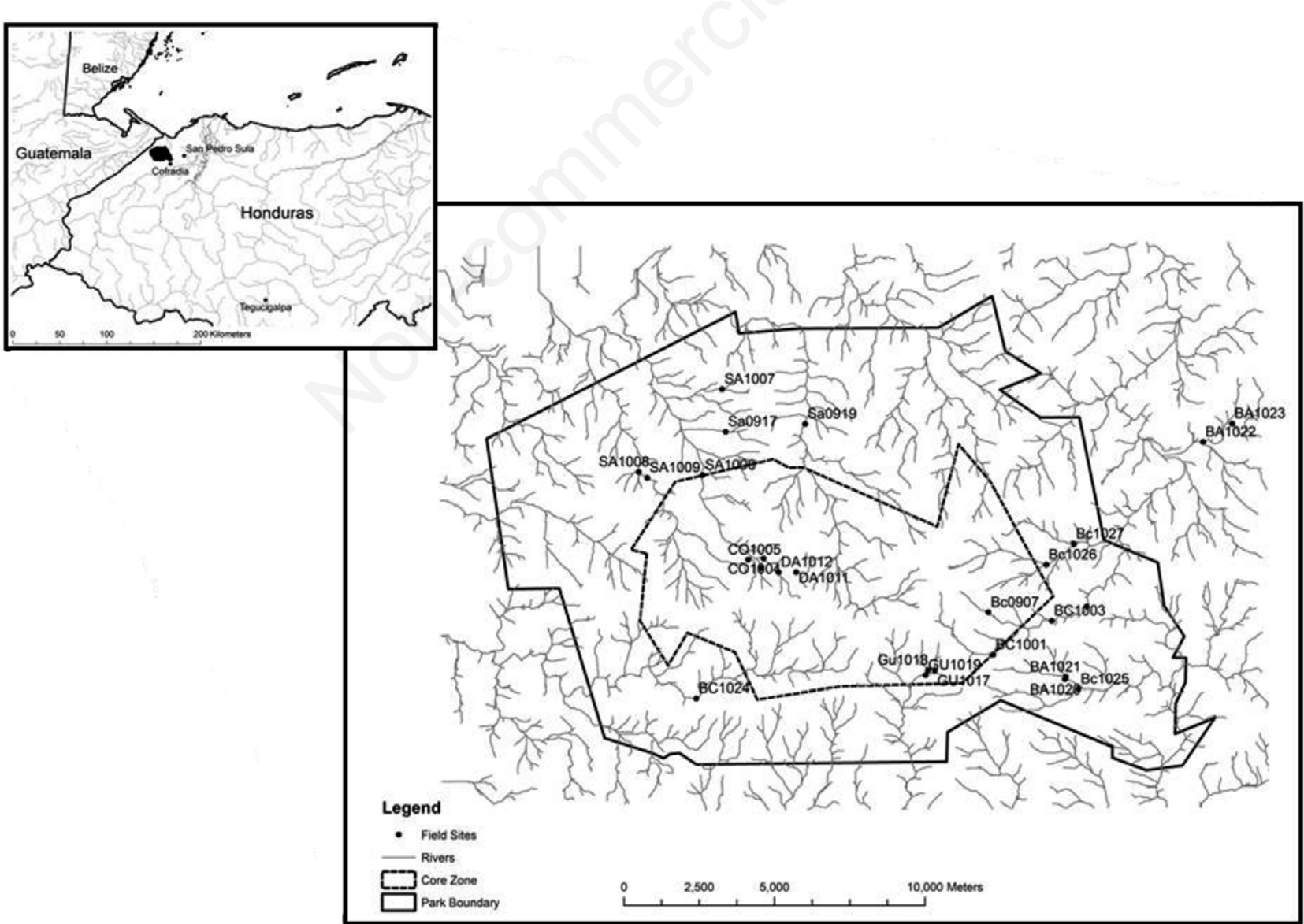

Fig. 1. Map showing location of el Parque Nacional Cusuco in Honduras and sampling site locations. 
were, $\mathrm{pH}$, representation of 6 substrate types (\% bedrock, $\%$ boulder, $\%$ cobble, $\%$ gravel, $\%$ sand and $\%$ silt $/$ mud), altitude, slope and the chemical variables iron and alkalinity. All substrate types were square root transformed while alkalinity and iron were $\log (\mathrm{x}+1)$ transformed. Only variables with the greatest influence on macroinvertebrate structure were overlaid as vectors on the PCoA plot. A Distance based Linear Model (DistLM) analysis was performed to see which environmental variables were the most significant in structuring the groups and how much of the dissimilarity they were responsible for. A SIMilarity PERcentages routine (SIMPER) was applied to determine the taxa driving any differences detected. Statistical analyses were conducted using Primer and Permanova+ ver. 6 .

\section{RESULTS}

Sites typically had water temperatures ranging from $16-24.7^{\circ} \mathrm{C}$, decreasing with increasing altitude (Tab. 1). Sites were generally characterised by a large proportion of riffle and run habitat, usually with few pools. Oxygen levels ranged between 7.16 and $9 \mathrm{mg} \mathrm{L}^{-1}$, and were usually circum-neutral pH (Tab. 2). Hardness values were typical

Tab. 1 Physical characteristics measured for stream sites in Cusuco National Park. Altitude and slope were calculated from GIS maps, all other parameters were measured at the time of invertebrate sampling.

\begin{tabular}{|c|c|c|c|c|c|c|c|c|c|c|}
\hline Sites & $\begin{array}{l}\text { Altitude } \\
\text { (m) }\end{array}$ & $\begin{array}{c}\text { Temperature } \\
\left({ }^{\circ} \mathrm{C}\right)\end{array}$ & $\begin{array}{l}\text { Shade } \\
(\%)\end{array}$ & $\begin{array}{c}\text { Substrate } \\
\text { exposed } \\
\text { bedrock }(\%)\end{array}$ & $\begin{array}{c}\text { Substrate } \\
\text { boulder } \\
(\%)\end{array}$ & $\begin{array}{c}\text { Substrate } \\
\text { Cobble } \\
(\%)\end{array}$ & $\begin{array}{c}\text { Substrate } \\
\text { gravel } \\
(\%)\end{array}$ & $\begin{array}{c}\text { Substrate } \\
\text { sand } \\
(\%)\end{array}$ & $\begin{array}{c}\text { Substrate } \\
\text { mud/silt } \\
(\%)\end{array}$ & $\begin{array}{c}\text { Slope } \\
\left(\mathrm{m} \mathrm{km}^{-1}\right)\end{array}$ \\
\hline BC1001 & 1600 & 17.7 & 50 & 0 & 15 & 20 & 25 & 40 & 0 & 111.897 \\
\hline $\mathrm{BC} 1002$ & 1100 & 19.9 & 25 & 0 & 40 & 20 & 15 & 25 & 0 & 141.057 \\
\hline BC1003 & 1300 & 19 & 50 & 0 & 20 & 20 & 10 & 50 & 0 & 56.624 \\
\hline CO1004 & 1500 & 17.1 & 50 & 10 & 30 & 20 & 10 & 30 & 0 & 211.509 \\
\hline $\mathrm{CO} 1005$ & 1400 & 17.8 & 25 & 0 & 20 & 30 & 30 & 20 & 0 & 90.346 \\
\hline SA1006 & 650 & 21.2 & 25 & 10 & 30 & 20 & 10 & 30 & 0 & 209.523 \\
\hline SA1007 & 600 & 22.6 & 75 & 0 & 30 & 10 & 10 & 20 & 30 & 207.253 \\
\hline SA1008 & 550 & 22.2 & 25 & 0 & 20 & 20 & 20 & 40 & 0 & 205.372 \\
\hline SA1009 & 600 & 22.6 & 25 & 0 & 40 & 20 & 10 & 30 & 0 & 97.509 \\
\hline DA1010 & 1500 & 17.6 & 50 & 0 & 20 & 30 & 20 & 30 & 0 & 88.329 \\
\hline DA1011 & 1600 & 17.6 & 75 & 0 & 0 & 0 & 0 & 100 & 0 & 37.251 \\
\hline DA1012 & 1600 & 17.2 & 75 & 0 & 5 & 20 & 25 & 50 & 0 & 111.463 \\
\hline CA1013 & 1800 & 18.6 & 10 & 30 & 10 & 25 & 25 & 10 & 0 & 134.425 \\
\hline CA1014 & 1800 & 16.5 & 10 & 5 & 20 & 20 & 25 & 30 & 0 & 141.703 \\
\hline $\mathrm{BC} 1015$ & 1950 & 15.1 & 75 & 5 & 25 & 35 & 25 & 10 & 0 & 229.276 \\
\hline GU1016 & 1000 & 21.6 & 5 & 0 & 30 & 40 & 30 & 0 & 0 & 169.455 \\
\hline GU1017 & 1300 & 18.5 & 50 & 10 & 40 & 30 & 15 & 15 & 0 & 144.769 \\
\hline GU1018 & 1300 & 18.8 & 75 & 0 & 20 & 20 & 20 & 40 & 0 & 205.68 \\
\hline GU1019 & 1300 & 18.9 & 75 & 0 & 35 & 30 & 25 & 10 & 0 & 174.314 \\
\hline BC1020 & 850 & 22.5 & 75 & 10 & 15 & 40 & 30 & 5 & 0 & 182.825 \\
\hline $\mathrm{BC} 1021$ & 850 & 22.7 & 75 & 60 & 5 & 5 & 0 & 0 & 30 & 67.693 \\
\hline BA1022 & 600 & 23.6 & 5 & 0 & 5 & 60 & 20 & 10 & 5 & 17.356 \\
\hline BA1023 & 700 & 24.7 & 10 & 5 & 5 & 10 & 20 & 30 & 30 & 90.191 \\
\hline BC1024 & 1000 & 22 & 10 & 5 & 20 & 40 & 25 & 10 & 0 & 69.046 \\
\hline $\mathrm{BC} 1025$ & 800 & 19.8 & 75 & 0 & 15 & 30 & 45 & 10 & 0 & 252.1 \\
\hline BC1026 & 1000 & 19 & 0 & 0 & 10 & 50 & 35 & 5 & 0 & 111.307 \\
\hline $\mathrm{BC} 1027$ & 900 & 22.8 & 10 & 0 & 15 & 40 & 40 & 5 & 0 & 141.132 \\
\hline BC0902 & 1400 & 17.8 & 50 & 0 & 20 & 40 & 10 & 10 & 20 & 340.32 \\
\hline BC0907 & 1700 & 16.4 & 50 & 0 & 25 & 25 & 20 & 30 & 0 & 180.789 \\
\hline CO0916 & 1500 & 16 & 75 & 0 & 20 & 50 & 0 & 30 & 0 & 145.832 \\
\hline SA0917 & 700 & 19 & 75 & 5 & 30 & 15 & 0 & 50 & 0 & 191.401 \\
\hline SA0919 & 640 & - & 25 & 5 & 50 & 5 & 10 & 30 & 0 & 181.435 \\
\hline
\end{tabular}


of soft waters: less than $50 \mathrm{mg} \mathrm{L}^{-1} \mathrm{CaCO}_{3}$ at all but 3 sites (55-65 mg L $\mathrm{LaCO}_{3}$ ). A small number of sites were characterised by high concentrations of iron (typical levels in drinking water are $0.3 \mathrm{mg} \mathrm{L}^{-1} \mathrm{Fe}$ (Who, 1996), maximum in Cusuco was $4.69 \mathrm{mg} \mathrm{L}^{-1}$ ). The iron mostly occurred as precipitates on the benthic substrates. Nutrient levels were generally low although some ortho-phosphate levels reached values $>0.05 \mathrm{mg} \mathrm{L}^{-1}$ (maximum $1.41 \mathrm{mg} \mathrm{L}^{-1} \mathrm{PO}_{4^{-}}$ P) (Tab. 2).

\section{Description of macroinvertebrate community}

A total of 136 invertebrate taxa representing 81 families were collected from 33 sites between 2009 to 2011 with an average taxon richness of 42 taxa per site. The most numerous taxon was the stonefly Anacroneuria (Perlidae) which was the only stonefly recorded. The community was heavily dominated (98.5\%) by insects. A total of 36,806 individuals were collected. This included 8854 Coleoptera (15 families, 24.06\%), 8721 Trichoptera (14

Tab. 2. Physico-chemical results for stream sites in Cusuco National Park. Those figures preceded by $<$ were below the detection limit of the mobile spectrophotometer. $\mathrm{O}_{2}$ and $\mathrm{pH}$ were measured at the time of invertebrate sampling, all other parameters were measured from June to August 2011.

\begin{tabular}{|c|c|c|c|c|c|c|c|c|c|}
\hline Sites & $\begin{array}{c}\text { Phosphate } \\
\mathrm{mg} \mathrm{L}^{-1} \\
\mathrm{PO}_{4}-\mathrm{P}\end{array}$ & $\begin{array}{l}\text { Nitrate } \\
\mathrm{mg} \mathrm{L}^{-1} \\
\mathrm{NO}_{3}-\mathrm{N}\end{array}$ & $\begin{array}{l}\text { Nitrite } \\
\mathrm{mg} \mathrm{L}^{-1} \\
\mathrm{NO}_{2}-\mathrm{N}\end{array}$ & $\begin{array}{c}\text { Ammonium } \\
\mathrm{mg} \mathrm{L}^{-1} \\
\mathrm{NH}_{4}-\mathrm{N}\end{array}$ & $\begin{array}{l}\text { Total } \\
\text { hardness } \\
\mathrm{mg} \mathrm{L}^{-1} \\
\mathrm{CaCO}_{3}\end{array}$ & $\begin{array}{l}\text { Iron } \\
\mathrm{mg} \mathrm{L}^{-1} \\
\mathrm{Fe}\end{array}$ & $\begin{array}{c}\mathrm{O}_{2} \\
\mathrm{mg} \mathrm{L}^{-1}\end{array}$ & $\begin{array}{l}\mathrm{O}_{2} \\
\%\end{array}$ & $\mathrm{pH}$ \\
\hline BC1001 & $<0.05$ & 0.7 & 0.005 & $<0.01$ & 10 & 0.09 & 8.5 & 101 & 6.77 \\
\hline $\mathrm{BC} 1002$ & $<0.05$ & 1.7 & 0.162 & $<0.01$ & 17.5 & 0.39 & 8.07 & 98.9 & 7.43 \\
\hline $\mathrm{BC} 1003$ & - & - & - & - & - & - & 8 & 99.9 & 7.66 \\
\hline CO1004 & 1.41 & $<0.5$ & 0.222 & 0.63 & 10 & 1.03 & 8.05 & 98.2 & 7.8 \\
\hline CO1005 & - & - & - & - & - & - & 7.9 & 97 & 7.62 \\
\hline SA1006 & - & - & - & - & - & - & 8.2 & 98 & 7.8 \\
\hline SA1007 & 1 & $<0.5$ & 0.17 & 0.506 & 47.5 & 0.88 & 7.8 & 95 & 7.84 \\
\hline SA1008 & 1.38 & $<0.5$ & 0.24 & 0.533 & 32.5 & 1.3 & 7.88 & 100 & 7.88 \\
\hline SA1009 & 1.33 & $<0.5$ & 0.165 & 0.684 & 30 & 0.96 & 7.8 & 97 & 7.77 \\
\hline DA1010 & - & - & - & - & - & - & 7.8 & 108 & 7.33 \\
\hline DA1011 & 1.38 & $<0.5$ & 0.24 & 0.655 & 65 & 1.24 & 8.03 & 100 & 7.22 \\
\hline DA1012 & 0.61 & $<0.5$ & 0.014 & 0.01 & $<12$ & 0.69 & 8.4 & 105 & 7.31 \\
\hline CA1013 & $<0.05$ & $<0.5$ & 0.006 & $<0.01$ & 20 & 0.27 & 8.4 & 108 & 4.47 \\
\hline CA1014 & $<0.05$ & $<0.5$ & 0.005 & $<0.01$ & 15 & 0.08 & 8.9 & 111 & 7.02 \\
\hline BC1015 & $<0.05$ & 0.5 & 0.006 & $<0.01$ & 7.5 & 0.03 & 8.7 & 108 & 6.8 \\
\hline GU1016 & $<0.05$ & 0.5 & 0.03 & $<0.01$ & 32.5 & 0.24 & 8.7 & 109 & 4.34 \\
\hline GU1017 & 0.08 & 0.6 & 0.014 & $<0.01$ & 22.5 & 0.13 & 9 & 112 & 6.6 \\
\hline GU1018 & $<0.05$ & $<0.5$ & 0.012 & $<0.01$ & 10 & 0.02 & 7.8 & 97 & 6.72 \\
\hline GU1019 & 0.05 & $<0.5$ & 0.014 & $<0.01$ & 45 & 0.14 & 7.9 & 100 & 6.98 \\
\hline BC1020 & $<0.05$ & $<0.5$ & 0.005 & $<0.01$ & 40 & 0.68 & 7.16 & 99.7 & 4.39 \\
\hline BC1021 & 0.1 & $<0.5$ & 0.024 & 0.024 & 55 & 4.69 & 8.36 & 96.2 & 4.7 \\
\hline BA1022 & 0.08 & $<0.5$ & 0.165 & $<0.01$ & 17.5 & 0.06 & 8.3 & 108 & 7.32 \\
\hline BA1023 & 0.06 & 0.7 & 0.01 & $<0.01$ & 17.5 & 0.07 & 8.3 & 107 & 8 \\
\hline $\mathrm{BC} 1024$ & $<0.05$ & $<0.5$ & 0.006 & $<0.01$ & 12.5 & 0.04 & 8.2 & 103 & 7.28 \\
\hline $\mathrm{BC} 1025$ & $<0.05$ & $<0.5$ & 0.004 & $<0.01$ & 30 & 0.1 & 8.7 & 104 & 7.31 \\
\hline BC1026 & $<0.05$ & 0.8 & 0.009 & $<0.01$ & 25 & 0.18 & 8.8 & 106 & 7.16 \\
\hline BC1027 & $<0.05$ & $<0.5$ & 0.005 & $<0.01$ & 25 & 0.35 & 8.4 & 105 & 7.2 \\
\hline ВC0902 & - & - & - & - & - & - & 8.97 & 109 & 6.04 \\
\hline ВC0907 & - & - & - & - & - & - & - & - & 6.5 \\
\hline CO0916 & - & - & - & - & - & - & - & - & - \\
\hline SA0917 & 0.97 & $<0.5$ & 0.106 & 0.06 & 17.5 & 0.67 & - & - & - \\
\hline SA0919 & 1.41 & $<0.5$ & 1.27 & 0.731 & 62 & 1.16 & - & - & - \\
\hline
\end{tabular}


families, 23.7\%), 6639 Diptera (14 families, 18.04\%), 4530 Ephemeroptera (5 families $12.31 \%$ ), 3836 Plecoptera (1 family, 10.4\%), 2498 Odonata (11 families, 6.78\%), 798 Hemiptera ( 9 families, 2.17\%), 584 Megaloptera (1 family, $1.59 \%$ ) and small numbers of Lepidoptera and Blattodea (both $0.1 \%$ ). There were few other groups and when present they occurred only in small numbers: $0.4 \%$ were Crustacea ( $0.3 \%$ Amphipoda and $0.1 \%$ Decapoda), $0.8 \%$ were mites mostly of the family Limnocharidae, and the remainder were Nematomorpha (hairworms), Platyheminthes (flatworms) and a single Hirudinea.

Coleopteran richness and abundance was dominated by Elmidae (28 genera) and Ptilodactylidae ( 2 genera). Hydropsychidae (2 genera) were the most commonly occurring Trichoptera followed by Leptoceridae (mostly Oecetis and Triplectides), Lepidostomatidae (Leptidostoma) and Odontoceridae (Marilia). Of 5 families of Ephemeroptera recorded the most common was Leptophlebiidae ( 2 genera) followed by Baetidae ( 3 genera) and Heptageniidae (1 genus) with small numbers of Leptohyphidae and Euthyplociidae at lower altitudes. Fourteen genera in 11 families of Odonata occurred with Coenagrionidae Argia and Gomphidae Epigomphus being the most abundant. The most commonly occurring Hemiptera were Veliidae and Naucoridae. Fourteen dipteran families were recorded, these were dominated by Chironomidae, Ceratopogonidae and Pediciidae. The Dobsonfly Corydalus was the only other taxon which occurred almost ubiquitously. The 2011 data are not presented further as only 5 sites were sampled along an altitudinal gradient of Rio Cusuco. These data added 2 new taxa, a Heteroceridae and an unidentified Elmidae.

The majority of sites had at least 30 taxa $(81 \%$ in both

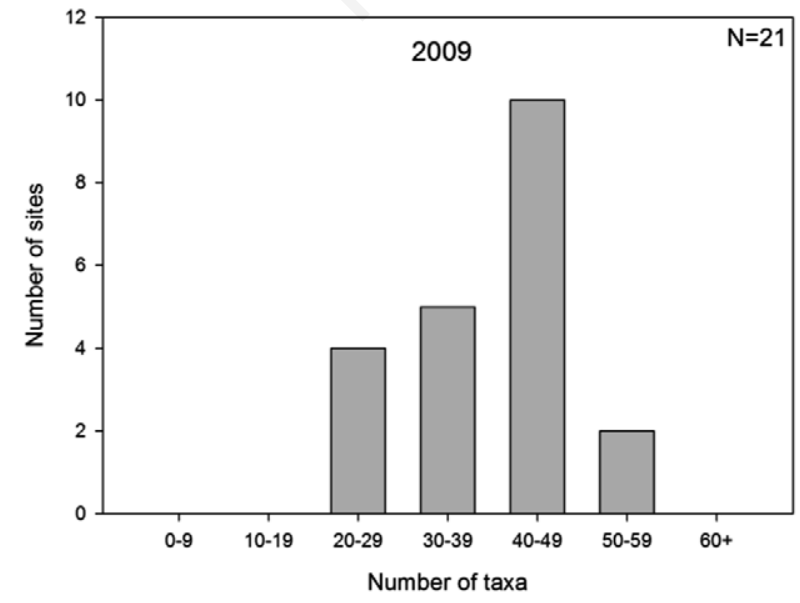

Fig. 2. Frequency distribution showing the ranges in total taxon richness at sites in 2009.
2009 and 2010) with no site having fewer than 20 taxa (Figs. 2 and 3). Taxon richness was similar across years although 2010 had some more sites with richness values in the 30-39 range. These were largely lower altitude sites $(<1000 \mathrm{~m}$ asl $)$ which were not sampled in 2009. Many taxa were uncommon, occurring at fewer than $10 \%$ of sites and present in only small numbers (Figs. 4 and 5). These were commonly rare Elmidae genera.

Of the 106 taxa which occurred in 2009, 32 were present in fewer than $10 \%$ of sites and 20 in more than $70 \%$ (Fig. 4). Between these extremes there was generally a more even distribution of taxon numbers. Tabs. 3 and 4 list those taxa occurring at more than $70 \%$ of sites. Of these the most ubiquitous were Anacroneuria (Perlidae), Pediciidae, Chironomidae, Oecetis (Leptoceridae) and Corydalus (Corydalidae). Polycentropus (Polycentropodidae) occurred at over $90 \%$ of sites in 2009 but only $41 \%$ of sites in 2010 (Tabs. 3 and 4).

\section{Distribution of taxa and environmental structuring variables}

The macroinvertebrate data separated into 5 significantly different groups (Fig. 6), 1 of these contained only 2 sites and PCoA showed 2 more to have considerable overlap, therefore the 3 distinct larger groups which separated at $40 \%$ similarity were chosen for examination of the influence of the measured physico-chemical variables.

Just over half of the variation $(51.9 \%)$ among the macroinvertebrate community was explained by Axes 1 and 2 of the PCoA plot (Fig. 7). A DistLM showed that $\mathrm{pH}$ accounted for the greatest amount $(\sim 25 \%)$ of the dissimilarity followed by altitude $(\sim 15 \%)$ and $\%$ sand $(\sim 6 \%)$. All but 3 members (GU1017, GU1019 and BC1025, pH

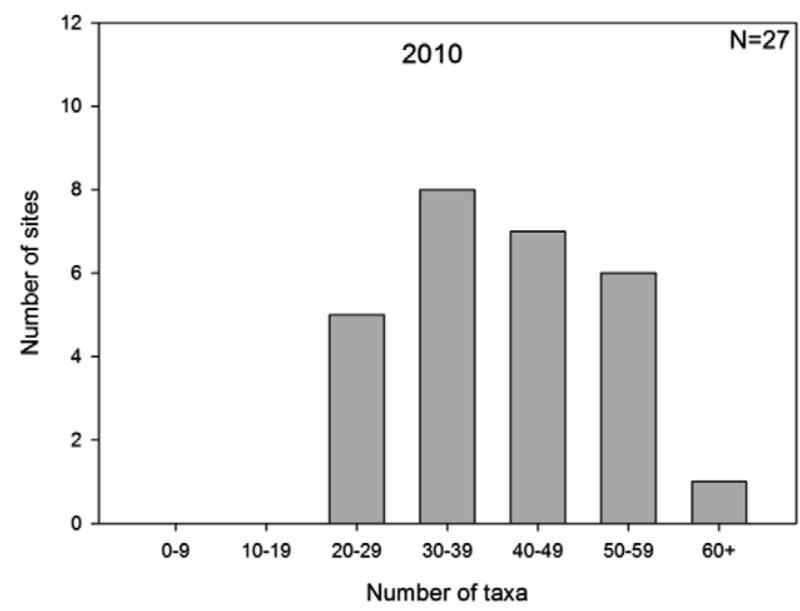

Fig. 3. Frequency distribution showing the ranges in total taxon richness at sites in 2010. 
6.6 and 6.98, and 7.31 respectively) of Group 1 had relatively low pH values (minimum 4.34) (Tab. 5).

With respect to altitude all sites in Group 2 were at $1300 \mathrm{~m}$ or higher (average $1563 \mathrm{~m}$; range $1300-1950 \mathrm{~m}$ ) (Tab. 5) and those of Group 3 were below $1100 \mathrm{~m}$ (average $757 \mathrm{~m}$, range $550-1100 \mathrm{~m}$ ) (Tab. 5). A subset of the sites in Group 2 including BC1001, CO1004, DA1011,

Tab. 3. List of taxa which occurred at more than $70-90 \%$ of those sites sampled in 2009 .

\begin{tabular}{lc} 
Family & Genus \\
$\frac{70 \%}{\text { Elmidae }}$ & \\
Odontoceridae & Cylloepus \\
Elmidae & Marilia \\
Psephenidae & Macrelmis \\
Gomphidae & Psephenus \\
\hline $80 \%$ & Epigomphus \\
\hline Calamoceratidae & \\
Hydropsychidae & \\
Lepidostomatidae & \\
Leptoceridae & \\
Ceratopogonidae & Lepidostoma \\
Simuliidae & Triplectides \\
Corydalidae & Ceratopogonidae \\
Elmidae & spp. indet \\
Veliidae & Corydalus \\
Coenagrionidae & Neoelmis \\
\hline $90 \%$ & Rhagovelia \\
Leptoceridae & Argia \\
Polycentropodidae & \\
Perlidae & Polycentropus \\
Chironomidae & Anacroneuria \\
Pediciidae & spp. indet. \\
\hline & \\
\hline
\end{tabular}

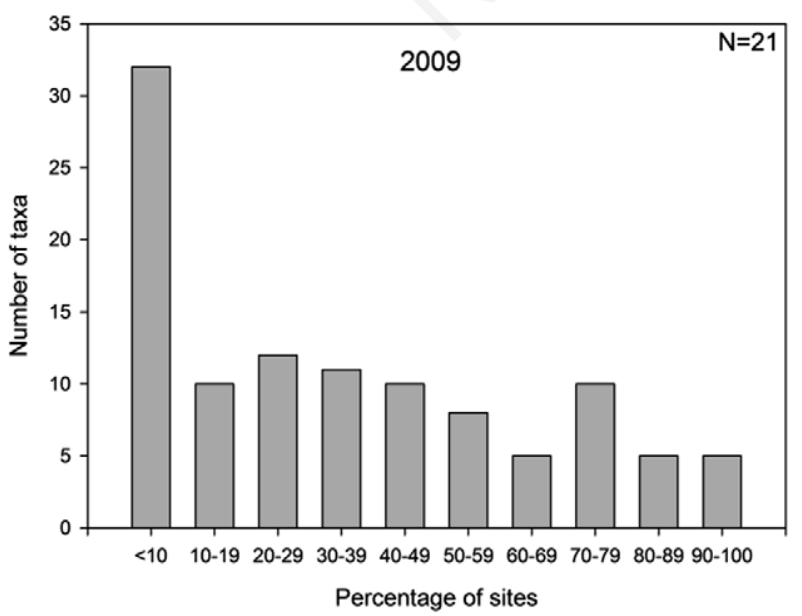

Fig. 4. Frequency distributions showing numbers of taxa which occurred in various percentages of sites in 2009 .
DA1012 and GU1018 had relatively high proportions of sand (greater than $30 \%$ in all cases) (Tab. 5), however these sites did not form a significantly different group based on the cluster analysis. The only member of this group which had less than 30\% sand was BC1015 (10\%) which was situated on a relatively steep gradient (Tab. 5).

The 3 groups of sites had distinctly different macroin-

Tab. 4. List of taxa which occurred at more than $70-90 \%$ of those sites sampled in 2010 .

\begin{tabular}{lc} 
Family & Genus \\
$\frac{70 \%}{\text { Odontoceridae }}$ & \\
Baetidae & Marilia \\
Leptophlebiidae & spp. indet. \\
Ptilodactylidae & Farrodes \\
Elmidae & Anchytarsus \\
Psephenidae & Cylloepus \\
Sciomyzidae & Psephenus \\
\hline$>80 \%$ & Sciomyzidae \\
\hline Leptoceridae & \\
Leptoceridae & Oecetis \\
Elmidae & Triplectides \\
Elmidae & Heterelmis \\
Elmidae & Neoelmis \\
Coenagrionidae & Macrelmis \\
Gomphidae & Argia \\
\hline$>90 \%$ & Epigomphus \\
\hline Perlidae & \\
Corydalidae & Anacroneuria \\
Chironomidae & Corydalus \\
Pediciidae & spp. Indet. \\
\hline
\end{tabular}

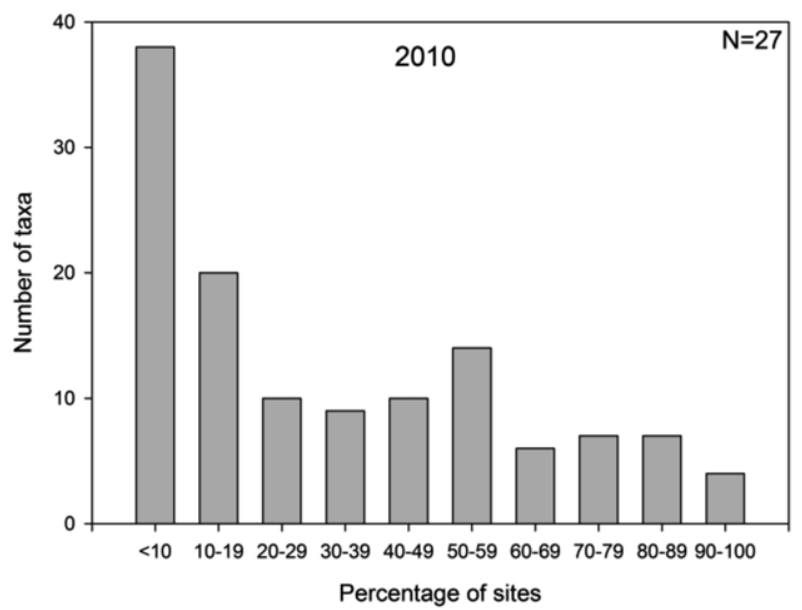

Fig. 5. Frequency distributions showing numbers of taxa which occurred in various percentages of sites in 2010 . 


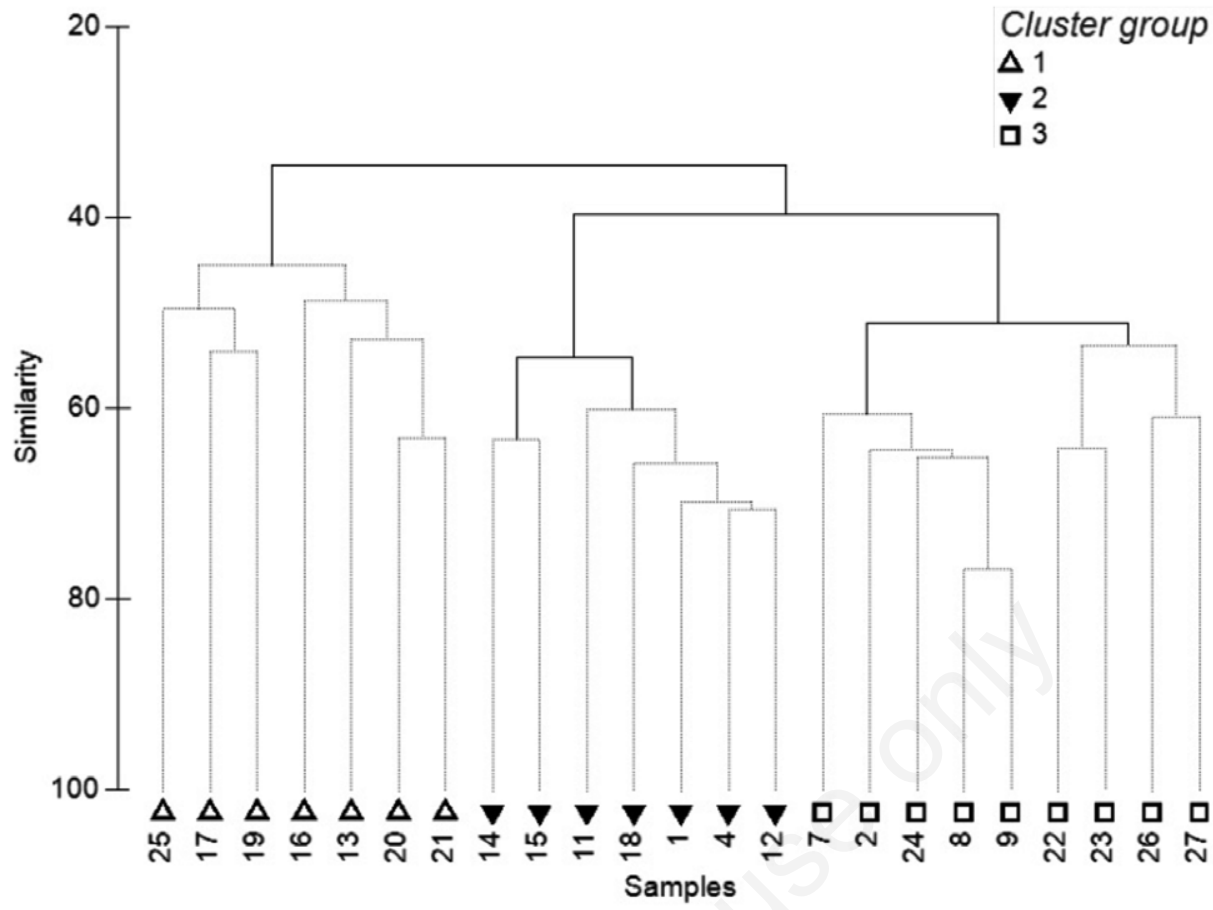

Fig. 6. Cluster dendrogram of sites sampled in 2010 for which water chemistry was available based on macroinvertebrate community structure. A SIMilarity PROFile (SIMPROF) test shows significantly different groups (significance level 1\%) (solid arms) at the relevant similarity level.

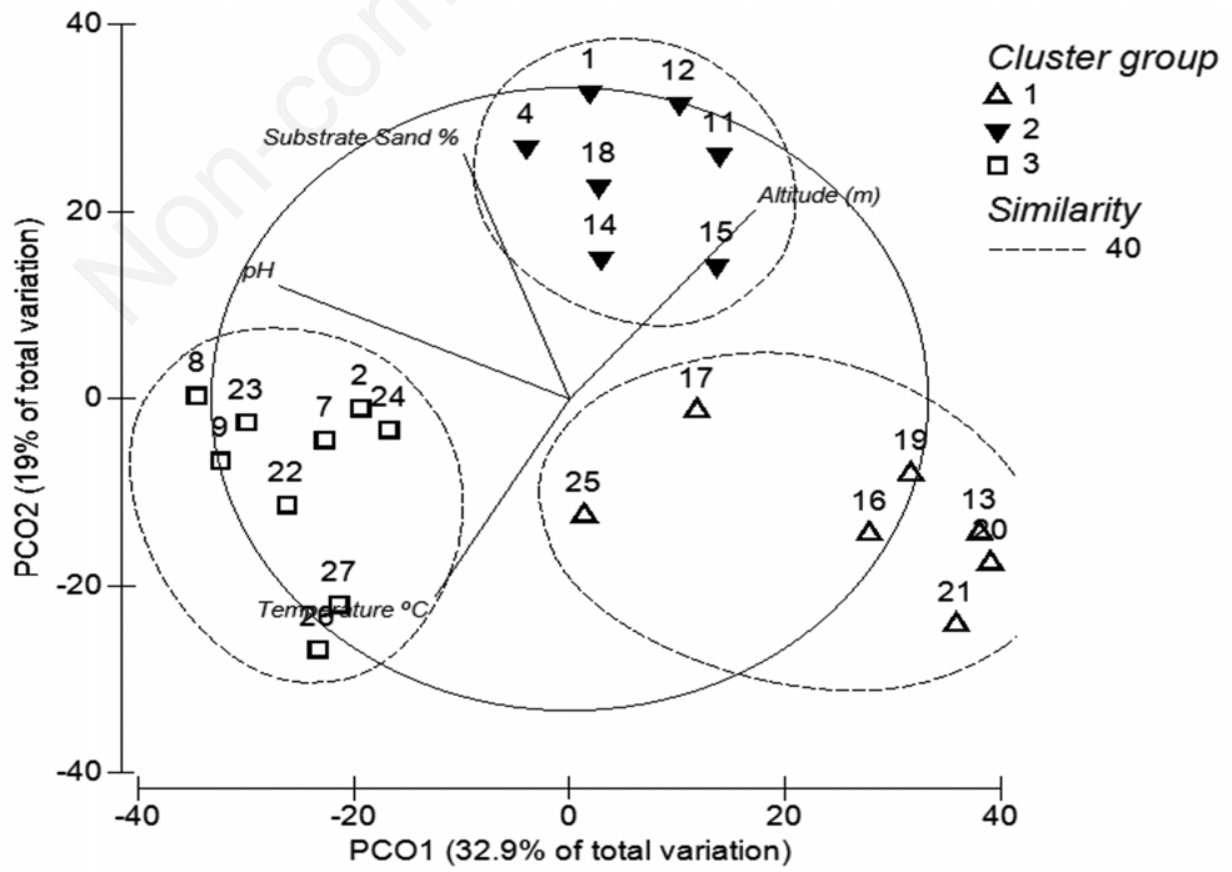

Fig. 7. PCoA plot showing 2010 sites where both environmental and chemical data were available separated based on macroinvertebrate assemblages and overlaid with environmental variables and clusters at $40 \%$ similarity. Altitude was calculated from GIS maps. Temperature, $\mathrm{pH}$ and substrate were measured at the time of invertebrate sampling. 
vertebrate abundances with the lowest in Group 1 at 86 individuals per kick sample, while Group 3 averaged 138 and Group 2 had the highest abundance at 254 per kick sample. The SIMPER analysis gave average dissimilarity between Groups 1 and 2 of $61.29 \%$, some $21.54 \%$ of which can be explained by higher abundances of Farrodes (Leptophlebiidae), Neoelmis (Elmidae), Psephenus (Psephenidae), Triplectides (Leptoceridae) and Marilia (Odontoceridae) in Group 2 (5.8\%, 4.99\%, 3.93\%, 3.45\% and $3.37 \%$, respectively). Average dissimilarity between Groups 1 and 3 was $68.77 \%$, where $21.14 \%$ was explained by higher abundances of Macrelmis (Elmidae), Limnocoris (Naucoridae) and Psephenus (Psephenidae) in Group 3 and higher abundances of Calosopsyche (Hydropsychidae) and Simuliidae in Group 1 (6.22\%, 3.82\%, 3.57\%, 3.92\% and $3.61 \%$ respectively). Finally, the average dissimilarity between Groups 2 and 3 (high and low altitude respectively) was $60.37 \%$. This was driven by a higher abundance of Farrodes (Leptophlebiidae), Calosopsyche Hydropsychidae, Neoelmis (Elmidae), Triplectides (Leptoceridae) and Pediciidae in group 2 contributing 19.41\% $(5.22 \%, 4.23 \%, 3.81 \%, 3.09 \%$ and $3.06 \%$ respectively) of the total dissimilarity between the groups.

\section{DISCUSSION}

The macroinvertebrate communities in the present study were heavily dominated both in terms of abundance and taxon richness by insects especially Coleoptera, Trichoptera, Diptera, Ephemeroptera, Plecoptera and Odonata with smaller numbers of Hemiptera, Megaloptera, Lepidoptera and Blattodea. The numerical dominance of the Coleoptera, Trichoptera, Diptera and
Odonata is broadly in agreement with other studies such as Jacobsen (2003) who reported a dominance of Ephemeroptera, Trichoptera and Diptera in the Ecuadorian Andes, Bücker et al. (2010) who similarly reported a dominance of insects in the Ecuadorian Andes and Lopéz (2010) working in southern Honduras who again reported rivers to be dominated by insects particularly Ephemeroptera, Hemiptera and Odonata. While Fenoglio et al. (2002) did not report abundances they observed generally comparable invertebrate taxa in unpolluted streams sampled in Nicaragua. Segura et al. (2007) who sampled 20 upland streams in Brazil found a similar number of coleopteran families as was found during the present study. In a 2003 study on the latitudinal distribution of Ephemeroptera, Plecoptera and Trichoptera Vinson and Hawkins (2003) found the richness of Trichoptera genera to peak at the equator, $40^{\circ} \mathrm{N}$ and $40^{\circ} \mathrm{S}$. Honduras sits at approximately $15^{\circ}$ North and it is therefore not surprising that streams in the present study support a large diversity of Trichoptera. The present study also recorded small numbers of other groups including Crustacea, Arachnida, Nematomorpha and Platyhelminthes. A large, unidentified species of aquatic gastropod was observed at certain sites on the west side of the park, this was referred to colloquially as 'Huta' and is used as a food resource by locals, however it was never found in a kick sample.

Over $80 \%$ of sites in both 2009 and 2010 had at least 30 taxa per site. Many taxa were rare with 32 occurring in fewer than $10 \%$ of sites in 2009 and 38 in 2010 . However, some 20 taxa in 2009 and 18 taxa in 2010 were also relatively ubiquitous occurring in over $70 \%$ of the sites sampled. It is evident that while certain taxa occur ubiquitously, sites are not numerically dominated by a few very abundant taxa.

Tab. 5. Ranges of physico-chemical structuring variables used in PCoAand DistLM analyses. Altitude and slope were calculated using GIS maps, iron and alkalinity were measured between June and August 2011. All other parameters were measured at the time of invertebrate sampling.

\begin{tabular}{|c|c|c|c|c|c|c|c|c|c|}
\hline \multirow[b]{2}{*}{ Sites } & \multicolumn{3}{|c|}{ Group 1} & \multicolumn{3}{|c|}{ Group 2} & \multicolumn{3}{|c|}{ Group 3} \\
\hline & Min & Max & Mean & Min & Max & Mean & Min & Max & Mean \\
\hline $\mathrm{pH}$ & 4.34 & 7.31 & 5.54 & 6.72 & 7.80 & 7.09 & 7.16 & 8.00 & 7.54 \\
\hline Substrate exposed bedrock (\%) & 0.00 & 60.00 & 15.71 & 0.00 & 10.00 & 2.86 & 0.00 & 5.00 & 1.11 \\
\hline Substrate boulder (\%) & 5.00 & 40.00 & 21.43 & 0.00 & 30.00 & 16.43 & 5.00 & 40.00 & 20.56 \\
\hline Substrate cobble (\%) & 5.00 & 40.00 & 28.57 & 0.00 & 35.00 & 19.29 & 10.00 & 60.00 & 30.00 \\
\hline Substrate gravel (\%) & 0.00 & 45.00 & 24.29 & 0.00 & 25.00 & 18.57 & 10.00 & 40.00 & 21.67 \\
\hline Substrate sand (\%) & 0.00 & 15.00 & 7.14 & 10.00 & 100.00 & 42.86 & 5.00 & 40.00 & 19.44 \\
\hline Substrate mud/silt (\%) & 0.00 & 30.00 & 4.29 & 0.00 & 0.00 & 0.00 & 0.00 & 30.00 & 7.22 \\
\hline Altitude (m) & 800.00 & 1800.00 & 1128.57 & 1300.00 & 1950.00 & 1621.43 & 550.00 & 1100.00 & 783.33 \\
\hline Iron $\left(\mathrm{mg} \mathrm{L}^{-1} \mathrm{Fe}\right)$ & 0.10 & 4.69 & 0.89 & 0.02 & 1.24 & 0.45 & 0.04 & 1.30 & 0.47 \\
\hline Alkalinity (mmol L-1) & 0.02 & 0.56 & 0.21 & 0.02 & 0.78 & 0.24 & 0.02 & 0.38 & 0.06 \\
\hline Slope $\left(\mathrm{m} \mathrm{km}^{-1}\right)$ & 67.69 & 252.10 & 160.80 & 37.25 & 229.28 & 149.83 & 17.36 & 207.25 & 120.02 \\
\hline
\end{tabular}


Boyero (2002) compared macroinvertebrate species lists from North to South America and found a much higher diversity in Central America despite the likelihood that taxonomic effort is lower in the region. According to Boyero's findings Central America is particularly rich in Ephemeroptera and Odonata species (35 and 86 respectively). This is partially supported by the present study, and while the 9 ephemeropteran genera recorded may not be particularly rich (these have not been identified to species level) the current list of Odonata species in the park stands at 38 (although not all have these have been observed in their nymphal stages and the nymphal stage of at least 1 species is spent in bromeliads). Conversely, other studies have found relatively low diversity in neotropical streams, for example Ramírez and Pringle (1998) found only 53 morphospecies in a Costa Rican stream and Cressa (1998) only 52 morphospecies from a river in Venezuela. Streams in the present study had an average of 42 taxa per site, these were mostly identified to genus level with some identified to family or order. Considering this, these streams are likely to be more diverse than those sampled by Ramírez and Pringle (1998) and Cressa (1998).

Comparisons between tropical and temperate streams are confounded by differences in sampling methodologies as well as differences in distributions of individual taxa, for example Plecoptera are primarily a temperate order with Central America being particularly depauperate (Fenoglio and Rosciszewska, 2003; Fochetti and Tierno De Figueroa, 2008) while Odonata are primarily a tropical order (Kalkman et al., 2008). However, the RIVPACS field sampling methodology used in the U.K. is similar to that used here except for the differences in the duration of the kick samples, 2 minute in the present study as opposed to 3 minutes for RIVAPCS (Wright et al., 1998). In the U.K., 637 standardised taxa were found across 614 sites with many of these identified to species level (Wright et al., 1996). Taxon richness per site varied from 31 to 134 taxa per site (Wright et al., 2000). In the present study invertebrates were identified to genus level with some groups such as Diptera identified to family level. The average 42 taxa per site found during the present study indicate these sites are likely to be in the middle of the range found in British streams, however all of these are at relatively high altitude (above $1000 \mathrm{~m}$ ). When we consider only comparable high altitude sites like those upland areas of Scotland and northern England (the vast majority of which would be well below $1000 \mathrm{~m}$ ) where extremely taxon-poor RIVPACS sites were found (Wright et al., 2000 ) it is likely that these tropical upland sites are much more taxon rich.

Sites clustered into 3 distinct groups at $40 \%$ similarity. This is not surprising as even though these sites were spread over 7 catchments they were in a relatively small geographic area (Cusuco National Park is only about 30 $\mathrm{km}$ across at its widest points). The difference between the 2 larger clusters (Groups 2 and 3) was clearly driven by differences in altitude with all sites in Group 2 at higher altitudes (above $1300 \mathrm{~m}$ ) and all those in Group 3 lower (below $1100 \mathrm{~m}$ ). Group 1 was related to low $\mathrm{pH}$. The effect of acidity on lotic macroinvertebrates has been well documented in temperate regions, resulting in altered community structure, increased drift, reduced adult emergence and lower species richness (Hall et al., 1980; Hall and Ide, 1987; Lepori et al., 2003). The presence of forestry has also been shown to exacerbate acidification (Kelly-Quinn et al., 1996; Dunford et al., 2012; Feeley et al., 2013) in temperate regions, in part driven by scavenging of atmospheric acid anions and also by organic acidity. The occult/horizontal precipitation characteristic of cloud forests such as Cusuco National Park commonly contains far higher concentrations of solutes than rain water (Beiderwieden et al., 2007). Considering Cusuco's proximity to the large industrial hub of San Pedro Sula this could potentially include the kinds of industrial pollutants associated with acidification. However, the impacts of acidification on tropical, and in particular on neotropical streams has received little attention (Small et al., 2012; Ardón et al., 2013). In the tropics the warm, wet climate creates the potential for high rates of $\mathrm{CO}_{2}$ production in the soil, subsurface water flows can dissolve this $\mathrm{CO}_{2}$ and transport it to streams, thereby resulting in natural acidification in relatively pristine areas. This can be exacerbated by more severe or prolonged dry seasons (Johnson et al., 2008; Small et al., 2012) which are predicted to occur in some tropical areas due to climate change (Milly et al., 2005). In La Selva research station, Costa Rica Ramírez et al. (2006) detected decreases in insect density and biomass over the course of a year concurrent with declines in pH and Ardón et al. (2013) observed an increase in invertebrate drift, especially Chironomidae and Ephemeroptera, in response to a decreases in $\mathrm{pH}$. While in the present study Chironomidae were reasonably well represented in acidic (Group 1) sites the ephemeropteran fauna was distinctly depauperate with several taxa completely absent and those remaining represented by few or single individuals. Clearly further research is needed in this area.

Several of the sites in the low $\mathrm{pH}$ group also had high levels of iron precipitate which was obvious as a red coating on the benthic substrates, however substrate chemistry was not analysed in the present study. While almost no work has been conducted specifically on the effects of iron on tropical lotic macroinvertebrates, it has been shown in temperate regions to have a profound effect, with for example an increase from $0.2-0.3 \mathrm{mg} \mathrm{L}^{-1}$ dissolved iron reducing taxon richness from 67 to 53 taxa in a Danish river (Rasmussen and Lindegaard, 1988). The 
effects of acid mine drainage have been documented in the tropics with detrimental effects on macroinvertebrate communities resulting from various metals including copper (David, 2003). Considering the natural occurrence of iron-rich streams it would therefore be of great interest to quantify the effect of dissolved and precipitated iron on the macroinvertebrate assemblage in tropical streams.

There have been several studies conducted in the neotropics that have highlighted the effect of altitude on lotic macroinvertebrate community structure. These include the Ecuadorian Andes (Jacobsen, 2003), Brazil (Baptista et al., 2001), Bolivia (Tomanova et al., 2007) and Argentina (Dominguez and Ballesteros Valdez, 1992). The patterns are typical of the river continuum concept (Vannote et al., 1980) with a shredder dominated community at higher elevations (and lower order streams) being gradually replaced by collectors/gatherers in lower altitude (and higher order) streams. A notable exception is the aforementioned study by Tomanova et al. (2007) in Bolivia which observed the opposite probably due to the extreme altitude of the study sites. Even relatively small elevational gradients have been proven to be important in structuring macroinvertebrate assemblages in the neotropics with studies reporting changes in invertebrate assemblages for example across gradients of 5-720 m asl (Greathouse and Pringle, 2006), 846-1071 m. (López et al., 2010) and Bispo et al. (2006) observing a response across a gradient of just $350 \mathrm{~m}$. In the present study the analysis showed distinct separation of sites above $1300 \mathrm{~m}$ and below $1100 \mathrm{~m}$. The 5 most important invertebrate taxa driving these differences were unsurprisingly from some of the most numerous orders, the Coleoptera, Ephemeroptera, Trichoptera and Diptera, with all of these (Farrodes, Calosopsyche, Neoelmis, Triplectides and Pediciidae) present in higher numbers at higher elevations.

\section{CONCLUSIONS}

It can be concluded that the macroinvertebrate communities of these minimally disturbed upland streams are represented almost exclusively by insects and can be broadly grouped into 3 categories based on these communities. This may have implications for any assessment of environmental impairment, for example the development of bioassessment metrics, and necessitate adjustments to take into account the differences between these 3 groups. This would be especially important in the case of Group 1 sites where lower macroinvertebrate abundance and taxon richness were recorded even though these are in areas with minimal anthropogenic disturbance. Furthermore, more groups may emerge, if more sites were sampled across a greater geographic area, for example the results indicated that substrate is likely to be influential and at least 1 other study in the region (Belize) has high- lighted the importance of geology (Carrie et al., 2015). Therefore, further sampling, taking in a greater geographic area as well as more environmental variables, than could be covered in the present study, would be necessary to produce a comprehensive stream typology for the area.

\section{ACKNOWLEDGMENTS}

We would like to thank the people of Cusuco National Park for their cooperation and guidance on the numerous excursions in the forest. We also thank Sinéad Marley for her hard work and assistance as well as the staff and volunteers of Operation Wallacea for supporting the project. Finally thanks to the Graduate Research Education Programme in sustainable development (GREP) funded jointly by Irish Research Council for Science Engineering and Technology (IRCSET) the Irish Research Council for Health and Social Sciences (IRCHSS) for funding the project.

\section{REFERENCES}

Ardón M, Duff JH, Ramírez A, Small GE, Jackman AP, Triska FJ, Pringle CM, 2013. Experimental acidification of two biogeochemically-distinct neotropical streams: buffering mechanisms and macroinvertebrate drift. Sci. Total Environ. 443:267-277.

Baptista DF, Dorvillé LFM, Buss DF, Nessiamian JL, 2001. Spatial and temporal organization of aquatic insects assemblages in the longitudinal gradient of a tropical river. Rev. Bras. Biol. 61:295-304.

Beiderwieden E, Schmidt A, Hsia YJ, Chang SC, Wrzesinsky T, Klemm O, 2007. Nutrient input through occult and wet deposition into a subtropical montane cloud forest. Water Air Soil Pollut. 186:273-288.

Bispo PC, Oliveira LG, Bini LM, Sousa KG, 2006. Ephemeroptera, Plecoptera and Trichoptera assemblages from riffles in mountain streams of Central Brazil: environmental factors influencing the distribution and abundance of immatures. Braz. J. Biol. 66:611-622.

Boulton AJ, Boyero L, Covich AP, Dobson M, Lake S, Pearson R, 2008. Are tropical streams ecologically different from temperate streams?, p. 257-284. In: D. David (ed.), Tropical stream ecology. Academic Press.

Boyero L, 2002. Insect biodiversity in freshwater ecosystems: is there any latitudinal gradient? Mar. Freshwater Res. 53:753755 .

Bruijnzeel LA, Hamilton LS, 2000. Decision time for cloud forests. HIP-UNESCO, Paris: $44 \mathrm{pp}$.

Bubb P, May I, Miles L, Sayer J. 2004. Cloud forest agenda. UNEP-WCMC, Cambridge: 36 pp.

Bücker A, Sondermann M, Frede H-G, Breuer L, 2010. The influence of land-use on macroinvertebrate communities in montane tropical streams-a case study from Ecuador. Fund. Appl.Limnol. 177:267-282.

Carrie R, Dobson M, Barlow J, 2015. The influence of geology and season on macroinvertebrates in Belizean streams: im- 
plications for tropical bioassessment. Freshwater Sci. 34:648-662.

Clarke KR, Gorley RN. 2006. Primer v6: user manual/tutorial. PRIMER-E.

Covich AP, 1988. Geographical and historical comparisons of neotropical streams: biotic diversity and detrital processing in highly variable habitats. J. N. Am. Benthol. Soc. 7:361-386.

Cressa C, 1998. Community composition and structure of macroinvertebrates of the river Camuri Grande, Venezuela. Verh. Internat. Ver. Limnol. 26:1853-1855.

Crowl TA, Mcdowell WH, Covich AP, Johnson SL, 2001. Freshwater shrimp effects on detrital processing and nutrients in a tropical headwater stream. Ecology 82:775-783.

David CPC, 2003. Establishing the impact of acid mine drainage through metal bioaccumulation and taxa richness of benthic insects in a tropical Asian stream (the Philippines). Environ. Toxicol. Chem. 22:2952-2959.

Dobson M, Magana A, Mathooko JM, Ndegwa FK, 2002. Detritivores in Kenyan highland streams: more evidence for the paucity of shredders in the tropics? Freshwater Biol. 47:909-919.

Dominguez E, Ballesteros Valdez JM, 1992. Altitudinal replacement of Ephemeroptera in a subtropical river. Hydrobiologia 246:83-88.

Doumenge C, Gilmour D, Pérez MR, Blockhus J. 1995. Tropical montane cloud forests: conservation status and management issues, p. 24-37. In L.S. Hamilton, J.O. Juvik and F.N. Scatena [eds.], Tropical montane cloud forests. Springer-Verlag.

Dudgeon D, 2012. Responses of benthic macroinvertebrate communities to altitude and geology in tributaries of the Sepik River (Papua New Guinea): the influence of taxonomic resolution on the detection of environmental gradients. Freshwater Biol. 57:1794-1812.

Dunford RW, Donoghue DNM, Burt TP, 2012. Forest land cover continues to exacerbate freshwater acidification despite decline in sulphate emissions. Environ. Pollut. 167:58-69.

Edmunds G, Jensen S, Berner L, 1976. The mayflies of North and Central America. University of Minnesota Press, Minneapolis: $344 \mathrm{pp}$.

Feeley HB, Bruen M, Blacklocke S, Kelly-Quinn M, 2013. A regional examination of episodic acidification response to reduced acidic deposition and the influence of plantation forests in Irish headwater streams. Sci. Total Environ. 443:173-183.

Fenoglio S, Badino G, Bona F, 2002. Benthic macroinvertebrate communities as indicators of river environment quality: an experience in Nicaragua. Rev. Biol. Trop. 50:1125-1132.

Fenoglio S, Rosciszewska E, 2003. A characterization of the egg capsules of Anacroneuria starki and A. talamanca (Plecoptera: Perlidae), with a suggestion about the distribution of stoneflies in the Tropics. Folia Biol. (Krakow) 51:159-164.

Ferréol M, Dohet A, Cauchie HM, Hoffmann L, 2005. A Topdown approach for the development of a stream typology based on abiotic variables. Hydrobiologia 551:193-208.

Fochetti R, Tierno De Figueroa J, 2008. Global diversity of stoneflies (Plecoptera; Insecta) in freshwater. Hydrobiologia 595:365-377.

Förster S, 2001. The dragonflies of Central America exclusive of Mexico and the West Indies: A guide to their identification. Gunnar Rehfeldt.

Gonçalves JF, França JS, Medeiros AO, Rosa CA, Callisto M,
2006. Leaf breakdown in a tropical stream. Int. Rev. Hydrobiol. 91:164-177.

González-Espinosa M, Meave JA, Lorea-Hernández FG, IbarraManriquez G, Newton AC. 2011. The red list of Mexican cloud forest trees. Fauna \& Flora International, Cambridge: $152 \mathrm{pp}$.

Greathouse EA, Pringle CM, 2006. Does the river continuum concept apply on a tropical island? Longitudinal variation in a Puerto Rican stream. Can. J. Fish. Aquat. Sci. 63:134-152.

Hall RJ, Ide FP, 1987. Evidence of acidification effects on stream insect communities in central Ontario between 1937 and 1985. Can. J. Fish. Aquat. Sci. 44:1652-1657.

Hall RJ, Likens GE, Fiance SB, Hendrey GR, 1980. Experimental acidification of a stream in the Hubbard Brook experimental forest, New Hampshire. Ecology 61:976-989.

Hamilton LS, 1995. Mountain cloud forest conservation and research: a synopsis. Mt. Res. Dev. 15:259-266.

Hostettler S, 2002. Tropical montane cloud forests: a challenge for conservation. Bois Forets Tropiques 4:19-31.

Jackson JK, Sweeney BW, 1995a. Present status and future directions of tropical stream research. J. N. Am. Benthol. Soc. 14:5-11.

Jackson JK, Sweeney BW, 1995b. Research in tropical streams and rivers: introduction to a series of papers. J. N. Am. Benthol. Soc. 14:2-4.

Jacobsen D, 2003. Altitudinal changes in diversity of macroinvertebrates from small streams in the Ecuadorian Andes. Arch. Hydrobiol. 158:145-167.

Johnson MS, Lehmann J, Riha SJ, Krusche AV, Richey JE, Ometto JPHB, Couto EG, 2008. CO2 efflux from Amazonian headwater streams represents a significant fate for deep soil respiration. Geophys. Res. Lett. 35:L17401.

Johnson RK, 1998. Spatiotemporal variability of temperate lake macroinvertebrate communities: detection of impact. Ecol. Appl. 8:61-70.

Kalkman V, Clausnitzer V, Dijkstra K-D, Orr A, Paulson D, Tol J, 2008. Global diversity of dragonflies (Odonata) in freshwater. Hydrobiologia 595:351-363.

Kelly-Quinn M, Tierney D, Coyle C, Bracken JJ, 1996. Factors affecting the susceptibility of Irish soft-water streams to forest-mediated acidification. Fish. Manage. Ecol. 3:287-301.

Lepori F, Barbieri A, Ormerod SJ, 2003. Effects of episodic acidification on macroinvertebrate assemblages in Swiss alpine streams. Freshwat. Biol. 48:1873-1885.

Li AO, Dudgeon D, 2009. Shredders: species richness, abundance, and role in litter breakdown in tropical Hong Kong streams. J. N. Am. Benthol. Soc. 28:167-180.

López LI, Gutiérrez P, José MM, 2010. [Macrofauna acuática de la Quebrada Santa Inés, subcuenca del Río Yeguare, Honduras].[Article in Spanish]. Ceiba 51:17-28.

Lopez LI, Mora JM. 2014. [Honduras, p. 245-290]. In: P. Alonso-Eguílis, J.M. Mora, B. Campbell and M. Springer (eds.), [Diversidad, conservacion y uso de los macroinvertebrados dulceacuicolas de México, Centroamerica, Colombia Cuba y Puerto Rico].[Book in Spanish]. Instituto Mexicano de Tecnología del Agua.

Masese FO, Kitaka N, Kipkemboi J, Gettel GM, Irvine K, Mcclain ME, 2014. Macroinvertebrate functional feeding groups in Kenyan highland streams: evidence for a diverse shredder guild. Freshwater Sci. 33:435-450. 
Mathuriau C, Chauvet E, 2002. Breakdown of leaf litter in a neotropical stream. J. N. Am. Benthol. Soc. 21:384-396.

Maue T, Springer M, 2008. Effect of methodology and sampling time on the taxa richness of aquatic macroinvertebrates and subsequent changes in the water quality index from three tropical rivers, Costa Rica. Rev. Biol. Trop. 56:257-271.

Milly PCD, Dunne KA, Vecchia AV, 2005. Global pattern of trends in streamflow and water availability in a changing climate. Nature 438:347-350.

Moya N, Hughes RM, Domínguez E, Gibon F-M, Goitia E, Oberdorff T, 2011. Macroinvertebrate-based multimetric predictive models for evaluating the human impact on biotic condition of Bolivian streams. Ecol. Indic. 11:840-847.

Quinn GP, Keough MJ, 2002. Experimental design and data analysis for biologists. Cambridge University Press, Cambridge: $553 \mathrm{pp}$.

Ramírez A, Pringle CM, 1998. Structure and production of a benthic insect assemblage in a neotropical stream. J. N. Am. Benthol. Soc. 17:443-463.

Ramírez A, Pringle CM, Douglas M, 2006. Temporal and spatial patterns in stream physicochemistry and insect assemblages in tropical lowland streams. J. N. Am. Benthol. Soc. 25:108-125.

Rasmussen K, Lindegaard C, 1988. Effects of iron compounds on macroinvertebrate communities in a Danish lowland river system. Water Res. 22:1101-1108.

Sandin L, Verdonschot PFM. 2006. Stream and river typologiesmajor results and conclusions from the STAR project, p. 3337. In: M. Furse, D. Hering, K. Brabec, A. Buffagni, L. Sandin and P.M. Verdonschot (eds.), The ecological status of European rivers: evaluation and intercalibration of assessment methods. Springer.

Segura MO, Fonseca-Gessner AA, Tanaka MO, 2007. Composition and distribution of aquatic Coleoptera (Insecta) in low-order streams in the state of São Paulo, Brazil: influence of environmental factors. Acta Limnol. Brasil. 19:247-256.

Small GE, Ardón M, Jackman AP, Duff JH, Triska FJ, Ramírez A, Snyder M, Pringle CM, 2012. Rainfall-driven amplification of seasonal acidification in poorly buffered tropical streams. Ecosystems 15:974-985.

Springer M, 1998. Genera of aquatic insects from Costa Rica, deposited at the Museo de Zooiogia, Universidad de Costa Rica. Rev. de Biol. Trop. 46:137-141.
Springer M, Hanson P, Ramírez A. 2010. Macroinvertebrados de agua dulce de Costa Rica I. Revista de Biologia Tropical.

Tomanova S, Tedesco PA, Campero M, Van Damme PA, Moya N, Oberdorff T, 2007. Longitudinal and altitudinal changes of macroinvertebrate functional feeding groups in neotropical streams: a test of the River Continuum Concept. Fund. Appl. Limnol. 170:233-241.

Turak E, Koop K, 2008. Multi-attribute ecological river typology for assessing ecological condition and conservation planning. Hydrobiologia 603:83-104.

Vannote RL, Minshall GW, Cummins KW, Sedell JR, Cushing CE, 1980. The river continuum concept. Can. J. Fish. Aquat. Sci. 37:130-137.

Verdonschot PFM, Nijboer RC, 2004. Testing the European stream typology of the Water Framework Directive for macroinvertebrates. Hydrobiologia 516:35-54.

Vinson MR, Hawkins CP, 2003. Broad-scale geographical patterns in local stream insect genera richness. Ecography 26:751-767.

Wantzen KM, Ramírez A, Winemiller KO, 2006. New vistas in Neotropical stream ecology - Preface. J. N. Am. Benthol. Soc. 25:61-65.

WHO, 1996. Iron in drinking-water: background document for development of WHO guidelines for drinking water quality. World Health Organization, Geneva. Available from: http://www.who.int/water_sanitation_health/dwq/chemicals/ir on.pdf

Williams WD, 1988. Limnological imbalances: an antipodean viewpoint. Freshwater Biol. 20:407-420.

Wright JF, Blackburn JH, Gunn RJM, Furse MT, Armitage PD, Winder JM, Symes KL, Moss D, 1996. Macroinvertebrate frequency data for the RIVPACS III sites in Great Britain and their use in conservation evaluation. Aquat. Conserv. 6:141-167.

Wright JF, Furse MT, Moss D, 1998. River classification using invertebrates: RIVPACS applications. Aquat. Conserv.. 8:617-631.

Wright JF, Sutcliffe DW, Furse MT. 2000. Assessing the biological quality of fresh waters: RIVPACS and other techniques. In: J.F. Wright, D.W. Sutcliffe and M.T. Furse (eds.), The RIVPACS International Workshop. Freshwater Biological Association, Ambleside, UK. 